\title{
A generációs elméletek értelméről
}

\author{
Székely Levente \\ https://doi.org/10.51624/SzocSzemle.2020.1.7
}

\section{A szocializáció nemzedékformálása}

Az elmúlt évtizedek ifúságelméleti megközelítését két domináns diskurzus uralta, amelyek értelmezési keretet biztosítottak az ifúsági vonatkozású elméleti munkákhoz, empirikus kutatásokhoz és köztük a nemzetközi összehasonlító vizsgálatokhoz. Ez a két kiemelt tematika az élethelyzet bemutatásán alapuló „átmenet” diskurzusa és az életmódot középpontba helyező ifjúsági „kultúra” diskurzusa (Szanyi 2018). Az ifjúság megismerésében az uralkodó diskurzusok mellett helyet kapnak más megközelítések, olyanok is, amelyek magyar elméleteket inspiráltak. Nagy és Tibori (2016) három, kifejezetten a magyarországi viszonyokra reflektáló jelentősebb elméleti megközelítést emel ki: az ifjúsági korszakváltás elméletét (Gábor 2004), az ifjúságügy narratíváját (Nagy 2013b) és az új csendes generáció paradigmáját (Székely 2014). Az ifjúsági korszakváltás az átmenet diskurzusához kapcsolódik szorosan, míg az ifúságügy narratívája a fejlődéslélektani megközelítések közé illeszkedik, az új csendes generáció koncepciója pedig a generációs elméletek mentén fogalmazódik meg. Annak ellenére, hogy a generációs narratíva nem tekinthető az ifúságelmélet domináns diskurzusának, jelentősége növekszik (Szanyi 2018).

A generációs megközelítés a tudományos berkeken kívül, a mindennapok közbeszédében is jelentős sikereket ért el. Elsősorban az új nemzedékek megértésével kapcsolatban váltak népszerűvé a generációs tematikával foglalkozó, elsősorban pszichológiai megközelítéssel operáló humánerőforrás-menedzsment és marketing tárgykörébe sorolható könyvek, cikkek, előadások (Székely 2020). Mindezek azonban inkább nem segítik a generációs megközelítés mint tudományos narratíva létjogosultságának igazolását. Az a tény azonban, hogy valamilyen elmélet a tudományon kívüli terekben is népszerü, nem feltétlenül von le az értékéből. Elvitathatatlanul jogos kritika ugyanakkor a generációs megközelítésmóddal szemben, hogy a magyarázóereje sok tekintetben elmarad az alternatívákhoz képest. Könnyen beláthatjuk mindezt, ha például a gazdasági erőforrások vagy a lakóhely különbségeiből fakadó magyarázóerőre gondolunk. Nyilvánvaló, hogy a társadalom felső tizedébe tartozókat jórészt más kérdések foglalkoztatják, más a tevékenységszerkezetük is, mint az alsó tizedbe tartozóknak. Ahogyan az sem mindegy, hogy hol él az ember, hiszen a rurális környezetben élők mindennapjai nyilvánvalóan különböznek a nagyvárosokban élők mindennapjaitól. 
Mindazonáltal azt gondolom, hogy az új nemzedékek megértésében a generációs logika segíthet, többdimenziós szemlélete izgalmasabb az alternatív megközelítéseknél, hiszen azzal a kérdéssel foglalkozik, hogy milyenek a mai fiatalok. A kérdés magában hordozza a jövőről való gondolkodást is, hiszen a ma fiataljai fogják a későbbiekben formálni a világot, de formálják ma is, sőt bizonyos tekintetben már születésükkel vagy meg nem születésükkel - is tették (Székely 2020).

Mannheim (1969) megállapítása szerint a generációk közötti különbségek nem életkori jellegűek, hanem a megélt szocializációs tapasztalat különbözőségeiből erednek. Mindebből következhet, hogy ha az adott szocializációs hatások időben tartósnak bizonyulnak, és fennállnak a szocializáció legfontosabb életszakaszaiban (gyermek- és fiatalkor), akkor meghatározhatják egy-egy generáció karakterét.

Nagy és Trencsényi (2012) a szocializációs közegekről szóló munkájukban Giddens elméletéből kiindulva - amellett érvelnek, hogy a hagyományos, kételemú (család és iskola), illetve háromelemű (család, iskola és munka világa) „szocializációs közeg”-modellek kiegészítésre szorulnak. A szocializációs közegek vagy ágensek Giddens szerinti felosztásában is megjelennek a két- és háromelemű modellekből hiányzó tömegkommunikációs eszközök. Nagy és Trencsényi (2012) szerint beszélhetünk olyan harmadlagos szocializációs közegről, amely alapvetően a családon és iskolán kívüli szabadidő különböző tereit hordozza magában, illetve a szocializáció egyes jellemzőiben negyedleges közegről is, amely az információs társadalom virtuális tereit tartalmazza.

Aszocializációs közegek természete alapvetően különbözhet egymástól, míg az elsődleges családi közeg a maga természetességével az ősidőktől fogva jelen van és a társadalom alapeleme, addig a másodlagos iskola feltételez egy fejlettségi és intézményesültségi fokot (közoktatás), amely jellemzően egybeesik a nemzetállamok kialakulásával ${ }^{1}$.

A harmadlagos és a negyedleges szocializációs közegek kikristályosodása ${ }^{2}$ nyilvánvalóan egybeesik az információs társadalom megszületésével, kiépülése a 60-as évek óta folyamatos. Az ipari társadalom racionalitásának (mellék)terméke a gyermek- és ifúkori szabadidő, amelynek csak egy része intézményesült. A nem intézményesített szabadidőben egyre fontosabbá válik az elektronikus média: kezdetben a rádió, majd a televízió és ma már az internet tölti ki a szabadidő nagy részét. A szabadidő elektronikus gyarmatosításáról tanúskodnak a Magyar Ifjúság 2012 adatai (Nagy 2013a) mellett az időmérleg-vizsgálatok is (Nyeste 2003). A szabadidő nem intézményesült és intézményesült terei mellett olyan közegekben és tevékenységek mellett is helyet szorítanak neki, amelyeket korábban a család, az iskola vagy éppen a munka uralt.

1 Szervezett oktatás ugyan már az ókori Egyiptomban is létezett, ugyanakkor a társadalom nagy részét átfogó, általános, formális oktatási tevékenység a modern nemzetállamok sajátja.

2 Habár a hagyományos és az új média meglehetősen sok tekintetben különböznek egymástól, a konvergencia folyamatainak köszönhetően az integráció irányába mutatnak. A tartalmak konvergenciájának eredményeképpen akár egy közegként is értelmezhetjük mindazt, ami a hagyományos és az új médiatérben megjelenik. 


\section{Magyar (média)generációk}

A szocializáció folyamata társadalmi lénnyé formálja az egyént, ami nemzedéki vonatkozásban is érvényes. A szocializációs közegek karaktert - önazonosságot vagy éppen külső azonosítást - társíthatnak egy-egy nemzedékhez, azonban ez nem szükségszerűen jár együtt azzal, hogy más karaktert rajzol meg a korábbi nemzedékek karakteréhez képest. A szocializációs közegek közül az elsődleges család és a másodlagos iskola (és munkahely) közege hosszú idő óta - lényegi elemeit tekintve - változatlan, míg a harmadlagos és még inkább a negyedleges szocializációs közeg befolyásoló hatásai néhány évtizede jelentek meg és foglaltak teret a szocializáció folyamatában (vö. Nagy-Trencsényi 2012). Ezt érzékelhetjük elősorban az amerikai társadalmat leíró modellekben, ahol a generációk bemutatása, sőt névadása során is a médiafogyasztási jellemzők kerülnek előtérbe (lásd a televízió generációja, netgeneráció). A generációs felosztás sokféle lehet ${ }^{3}$, az egyik legelterjedtebb az, amit Fekete és Nagy (2020) mutat be.

Jogos kritika ezekkel a modellekkel szemben, hogy szinte kivétel nélkül nem a magyar társadalom megértésének szándékával készültek. Mégsem haszontalanok, ha ugyanis elfogadjuk a szocializáció hatását a nemzedéki jellegre, találhatunk hasonlóságokat az amerikai és a magyar viszonyokban, amelyek megrajzolhatják a magyar generációk arcélét is. A II. világháború előtt születettek Magyarországon is recesszióval találkoztak gyermekkorukban a nagy gazdasági világválság hatására, ugyanúgy, mint nyugaton. A veterán nemzedék konzervatív beállítódású, a kemény munkát tisztelő, a társadalmi intézmények iránt elkötelezett ideálképe Magyarországon éppúgy élhet bennünk, mint él az Egyesült Államokban. Ahogy Fekete és Nagy (2020) is kiemelik, a nyugati baby boomnak Magyarországon az 1950-1956 közötti Ratkó-korszak feleltethető meg. Ez a generáció szocializációs közegeit tekintve meglehetősen különbözik a nyugati megfelelőitől. Gyermekkorát és ifjúságát meghatározzák a szocialista ideológia által uralt iskolai és szabadidős terek. A nyugati baby boom generációjának határait figyelembe véve elmondható, hogy a magyarországi 1946-1964-es kohorsz sokkal kevésbé tekinthető televíziós nemzedéknek $^{4}$. Ha elfogadjuk a nyugati besorolást kiindulópontként, elmondhatjuk, hogy a magyar X generáció derékhadát a Ratkó-unokák adják, akik még voltak úttörők, tehát a szocializmusban szocializálódtak, a rendszerváltást tinédzserként vagy fiatal felnőttként élték meg. A nyugati X generációtól való megkésettség jól érzékelhető: a magyar $\mathrm{X}$ generáció tagjait, ha a televízió hatását tekintjük, leginkább a nyugati baby boom nemzedékéhez hasonlíthatjuk.

Fontos kiemelnünk a magyarországi Y generációt, amely mérföldkőként azonosítható a generációs struktúrában. Ez a nemzedék gyakorlatilag behozta azokat a lemaradásokat, amelyek az előzőekre jellemzőek voltak. Az Y generáció már nagy-

3 Föleg, ami a generációs határokat illeti (Székely 2014).

4 Magyarországon 1957-ben heti három adásnappal indult meg a rendszeres televízióadás, amely 10 évvel később is csupán egymillió előfizetővel bírt. 
részt a rendszerváltás után éli gyermekkorát, és ebben a tekintetben sokkal inkább tekinthető igazi globális generációnak, mint a részben a szocialista viszonyok között nevelkedett korábbi nemzedékek. A rendszerváltást követően Magyarországon - történelmi léptékkel mérve - egy csapásra kapitalista, fogyasztói társadalom jött létre, amelyhez elsőként a fiatalok csatlakoztak, idomulva a nyugati országok ízléstrendjeihez, bár anyagi lehetőségeikben elmaradva azoktól (Székely 2008). McCrindle és Wolfinger (2010) arról írnak, hogy a nemzedéki (közös) jellemzők mára átlépték a korábban meglévő kulturális és szociogazdasági határokat. Somlai (2011) ezt úgy fogalmazza meg, hogy az ifúsági kultúrát a média közvetítésével globális sztenderdek alakítják. Mindezek azt jelenthetik, hogy a fiatal nemzedékekben több a közös, mint a különbség, legalábbis ami a fejlett világ társadalmait illeti ${ }^{5}$.

A hazai munkák jellemzően megmaradnak a nemzetközi kutatási eredmények idézésénél a generációs jellemzők, illetve még inkább a generációs határok tekintetében. Eddig egyetlen kísérlet történt a generációs logika empirikus adaptációjára a magyarországi viszonyokra vonatkozóan (Székely 2014). A modell legfontosabb korlátját az adja, hogy kifejezetten a médiafogyasztás jellegzetességein alapul. Ez a szükítés azonban mindenképpen árnyalható, hiszen a generációs összehasonlító munkák is jellemzően a médiafogyasztás különbségeire építenek, sőt a nemzedékek alternatív elnevezéseiben is ezek köszönnek vissza, különösen a fiatalabbak esetében.

A médiafogyasztás és a kor összefüggéseinek kérdésével foglalkozó vizsgálatok eredményei alapján megállapítható, hogy a médiafogyasztás különbözőségei évek múltán is fellelhetôk az egyes kohorszokban, így a nemzedéki jelleg is azonosítható (Pintér-Székely 2006; Székely 2006; 2007).

Megfigyelhettük, hogy a legfiatalabb generációkat jellemző magas internetezési arány és magának az internetnek a fontossága a kor emelkedésével is megmarad. Az idősebbek (X és baby boom generáció) körében a nyomtatott sajtó olvasása és a tévénézés mennyiségében fedezhetünk fel tartós dominanciát. Mindezek mentén - megfeleltetve a magyar viszonyoknak a népszerü felosztások elnevezéseit - a Veteránokat az 1938-1939 előtt születettekkel azonosíthatjuk, a Baby boom nemzedékének magyar megfelelői az 1940-1941 és 1968-1969 között születettek. A magyarországi X generáció tagjai 1970-1971 és 1978-1979 között születtek, az Y generáció 19801981 és 1992-1993 között születetteket jelenti, míg a Z generáció tagjai 1994-1995 után születtek. A fenti generációs határok léte statisztikai értelemben igazolható, azaz szignifikáns különbségek vannak az egyes nemzedékek médiafogyasztásában, médiához kapcsolódó viszonyában. Az empirikus adatok elemzése ugyanakkor arra is felhívja a figyelmet, hogy néhány évvel eltolt generációs határvonalak nagyon hasonló eredményeket hoznak, tehát a pontosabb határok kijelölésére ez a vizsgálati módszer nem alkalmas, vagy ilyen markáns határok nem is léteznek (Székely 2014).

5 Érdemes azért megjegyezni, hogy a fejlett világ elöregedő társadalmaiban az ifjúság lélekszámában és arányában is fogyó társadalmi csoport. Az életkort tekintve a fiatal társadalmak a fejlődő világban találhatók. 
$\mathrm{Az}$ azonos időben születetteket megkísérelhetjük generációkba terelni, különösebb fenntartás nélkül alkalmazva az amerikai társadalomra megalkotott besorolást, érdemes azonban ellenőrizni mindezt empirikusan is. 2017-ben több egymást követő nagymintás - hullámonként 2000 fő megkérdezésével készült -, a 18 évesekre és idősebbekre reprezentatív kutatásban arra kértük válaszadóinkat, hogy jellemezzék a saját generációjukat. Az önjellemzés egyik része volt a reflexió a saját nemzedék határaira, a következő kérdést tettük fel: „Az Ön megitélése szerint hány évesektöl hány évesekig tart az Ön generációja?”. A válaszok elemzését követően megállapíthatjuk, hogy több esetben mindössze 2-3 évnyi csúszás van az önazonosítás és a médiafogyasztáson alapuló generációs besorolás között. A veteránok saját generációjukat az 1951 előtt születettekre értették, a baby boom nemzedéke pedig az 1950 és 1966 között születettekhez sorolta saját nemzedékét. Az X generáció tagjai 1968 és 1982 között, az Y generáció tagjai 1978 és 1992 között, a Z generáció tagjai pedig 1987 és 1999 között születetteknek tartják saját nemzedéküket (Székely 2018). Megvizsgáltuk, hogy melyek azok a közös tulajdonságok, amelyeket generációs jellegúeknek tekintenek maguk az adott nemzedékbe tartozók ${ }^{6}$. Az eredmények azt mutatják, hogy az egyes nemzedékekbe tartozók különbözőképpen ítélik meg saját generációjukat. Az önjellemzések alapján megrajzolható karakter sok esetben hasonlít az adott generációval kapcsolatos jellemzésekhez. Az Y és a Z generáció karakterében erőteljesen jelen lévő médiavonatkozás visszaigazolását látjuk az „internet” említésében, de a legidősebbek esetében is következtethetünk erre az „otthon ülő" kategóriát látva (Székely 2018).

Összefoglalóan tehát három tényező igazolja a generációs megközelítés létjogosultságát az ifjúságról való gondolkodásban: egyrészt a generációs logika kapcsolódik a nemzetközi szakirodalom trendjeihez, aktuális divatáramlat, eredete ugyanakkor évtizedekkel korábbi. Másrészt nem pusztán nemzetközi vonatkozása van, létezik magyar viszonyokra adaptált, empirikusan validált generációs besorolás is. Végül a generációs megközelítés a legfontosabb kérdésre reflektál: milyen az új nemzedék?

\section{Csendes az új nemzedék?}

Az ifjúsággal kapcsolatban alapvető kérdés, hogy a fiatalok milyen viszonyban vannak az idősebbek által irányított társadalommal. Leegyszerúsítve ez a viszony lehet harmonikus vagy konfliktusokkal terhelt. A nagymintás ifjúságkutatás legutóbbi adatfelvételei azt mutatják, hogy a tizen- és huszonévesek alapvetően elfogadják azokat a társadalmi normákat, amelyeket készen kaptak, azaz a játékszabályokat be kívánják tartani, és alapvetően pozitívan tekintenek a szüleik nemzedékre (Székely 2018), sőt az „idősekről” is kifejezetten pozitív asszociációk élnek a fejükben (Székely-Benczes 2019). A nemzetközi folyamatokat szemlélve azonban nem tehetjük meg, hogy a har-

6 A kérdőíves kutatás során azt a kérdést tettük fel a mintába kerülteknek: „Milyen az Ön generációja? Kérem, mondjon három olyan szót, ami a legjobban jellemzi az Ön generációját!" 
monikus jövőkép mellett ne gondolkozzunk a konfliktusok lehetőségén. Már csak azért sem, mert az ifjúsághoz hozzátartozik - legalábbis eddig hozzátartozott - a lázadás, a fennálló szabályok megkérdőjelezése és újak kialakítása. Mindez abban az esetben is fontos, amikor sem a kutatási adatok, sem a hétköznapi tapasztalás nem mutatja - vagy legalábbis néhány évvel ezelőtt még nem mutatta - mindezt.

A nemzetközi folyamatokat szemlélve felfedezhetünk olyan jelenségeket, amelyek a feszültség meglétét és növekedését mutatják az egyes nemzedékek között. Az „OK boomer” jelensége például értelmezhető úgy, hogy a társadalmon belüli ellentét generációs alapon szerveződik, sőt azt is mondhatnánk, hogy internacionális generációs ellentétet ragad meg. A The New York Times úgy kommentálta a jelenséget, mint amely véget vet a generációk közötti barátságos viszonynak ${ }^{7}$. A nyilvánvaló újságírói túlzáson túl érdemes elgondolkodni azon, hogy miért tehetett szert hatalmas népszerűségre az „OK boomer” kifejezés ${ }^{8} 2019$ végén, amelyet az év szavának is választottak Új-Zélandon. Az „OK boomer” már kilépett a digitális világból ${ }^{9}$, és egyértelműen generációs alapon határolja el a „mi” és az „ő” társadalmi csoportokat.

Az utóbbi egy-két évtizedben Magyarországon, a fejlett világ más részéhez hasonlóan, az ifjúság fizikailag is megnyilvánuló lázadásai kérészéletűek voltak. Természetesen számos olyan példát mondhatunk, ahol a fiatalok normákat sértettek, és jellemzően az idősebbek nézeteivel szemben fogalmaztak meg radikális kritikát. Ennek extrém példái az Iszlám Állam ifjú harcosai vagy éppen feleségeik, akik jellemzően nyugat-európai szocializációs háttérrel léptek be a terrorszervezet kötelékébe. Kevésbé élesen, de a nemzedéki különbségek megfigyelhetők a brexit kapcsán, és az internetadó elleni budapesti tüntetés ifjúsági jellege is kétségtelen. Ezek a jelenségek azonban elszigeteltek, jellemzően kisebb csoportokat mozgattak meg, vagy konkrét probléma körül szerveződtek, és nem álltak össze a status quo tagadásává, pontosabban nem öltöttek fizikai formát. Azt állítom, hogy az utóbbi egy-két évtizedben a digitális világ volt az a terület, amely a fiatalok sajátjaként létezett, ha tetszik, ez volt az ellenkultúra, amely a mainstream kultúra árnyékában élt, ugyanakkor mindez fizikai valójában kevésbé mutatkozott meg. A digitális kultúra képes volt kielégíteni a fiatalok élménykeresési igényét. Virtuális tereiben valódi közösségek formálódtak, digitális tartalmai valódi élményt kínáltak, ráadásul mindez többé-kevésbé úgy ment végbe, hogy a felnőttek (szülők, tanárok, munkaadók) elől rejtve maradt.

Az ifjúság szerveződése továbbra is elsősorban a virtuális terekhez, a közösségi médiához kötődik. Ha megvizsgáljuk azokat a társadalmi kérdéseket, amelyek mentén a fiatalok csoportjai szerveződnek, sokféle tematikával találkozhatunk. A leg-

7 Taylor Lorenz: 'OK Boomer' Marks the End of Friendly Generational Relations. The New York Times. 2019. 10. 29. https://www. nytimes.com/2019/10/29/style/ok-boomer.html

8 Habár magát a kifejezést legelőször 2009-ben rögzítették, használata 2015-től indult el, és felfutását egy TikTokon megjelenő videónak köszönheti. Egy idősebb férfi által készített, a fiatalabb generációkat kritizáló videóra volt válasz az „OK boomer”.

9 Az „OK boomer" kifejezés egy új-zélandi képviselő parlamenti felszólalásában is elhangzott replikaként egy idősebb képviselötárs közbevágására adott válaszban. 
jelentősebb ezek közül a klímaváltozással kapcsolatos, amely mediatizált világunk központi kérdésévé vált az utóbbi években (Székely 2020).

A klímaváltozás rendre megjelenik az aktuális történésekben. A természeti katasztrófák tárgyalása során az egyik, ha nem az egyetlen kiváltó okként szerepel a klímaváltozás, de más aktuális témák narratívájában is szerepet kap, például a tömeges migrációval kapcsolatban (ld. klímamenekültek). Megfékezése általános politikai cél és marketingeszköz. A klímaváltozáshoz kapcsolódóan olyan új fogalmakkal ismerkedhetünk meg, mint a klímaszorongás, az ökodepresszió vagy éppen a klímavészhelyzet, amelyet 2019-ben az év szavának választottak az Oxford Languages ${ }^{10}$ munkatársai. Az utóbbi egy évben a klímaváltozáshoz kapcsolódó tömegdemonstrációk a résztvevőik életkorát tekintve kifejezetten fiatalosak voltak, kiterjedésük globális, jelentőségük - a felvonulók fiatal kora ellenére - nem lebecsülendő. A generációs logika iránt elkötelezettekben jogosan merülhet fel a kérdés, hogy a klímaváltozás körül zajló társadalmi diskurzus képes-e generációs élményt nyújtani, amely karakteres nemzedékké formálja a ma ifúságát.

A klímaváltozás ellen szavukat felemelő fiatalok jellemzően nem kínálnak általános választ arra a kérdésre, hogy miképpen lehet megakadályozni vagy mérsékelni a klíma megváltozásából fakadó negatív hatásokat, a felelősöket azonban rendre megnevezik. Ezek nem mások, mint az idősebb generáció tagjai, akik vállalatokat, országokat irányítanak, vagy pusztán egyszerű fogyasztóként nem figyelnek kellően a tevékenységük okozta környezetterhelésre. Részben a felelősök megnevezésének tekinthető az „OK boomer” jelensége.

Amennyiben elfogadjuk a fentebb megfogalmazottokat, és úgy gondolunk az új nemzedékekre, mint akik a globális trendek mentén formálódnak, vizsgálatra érdemesnek kell tartanunk Fekete és Nagy (2020) hipotézisét, miszerint a korábban tapasztalt csendesség eltúnik vagy visszaszorul. A mindennapokban láthatjuk azokat a jeleket, amelyek erre utalnak, habár az érzékelésünk szelektív ${ }^{11}$, amiben egyre kevésbé bízhatunk ${ }^{12}$. A 2020-as nagymintás ifjúságkutatás első eredményei minden bizonnyal még ebben az évben megjelennek, amelyek választ adhatnak a fentiekre, és jobban megismerhetővé tehetik a mai 15-29 éveseket.

\section{Irodalom}

Fekete M. - Nagy Á. (2020): Megszólal-e az Új csendes generáció? Avagy mit várhatunk az Ifjúság 2020 adatfelvétel eredményeképp? Szociológiai Szemle 30(1):

Gábor K. (2004): Ifjúsági korszakváltás. Új Ifjúsági Szemle, 2(4): 5-24.

10 https://languages.oup.com/word-of-the-year/

11 Jellemző, hogy elsősorban azokat vesszük figyelembe, amelyek a virtuális környezeten kívül a fizikai szférában is megmutatkoznak, pl. a Musical.ly (ma már TikTok) jelentöségét is csak akkor sejthette meg a magyar társadalom, amikor egy közönségtalálkozó miatt lebénult a budai közlekedés.

12 A konstruált valóságunk egyre inkább mediatizált, ahol a vízhangkamrák és az álhírek befolyásolják érzékelésünket. 
Mannheim K. (1969): A nemzedéki probléma. In Huszár T. - Sükösd M. (szerk.): Ifjúságszociológia. Budapest: Közgazdasági és Jogi Könyvkiadó, 31-67.

Mccrindle, M. - Wolfinger, E. (2014): The ABC of XYZ: Understanding the Global Generations. Sydney: McCrindle Research Pty Ltd.

Nagy Á. (2013a): Szabadidős tervek és tevékenységek. In Székely L. (szerk.) Magyar Ifjúság 2012. Tanulmánykötet. Budapest: Kutatópont, 211-229.

Nagy Á. (2013b): Az ifúsági korosztályok meghatározásának egyéni életúton alapuló paradigmája. In Székely L. (szerk.): Magyar Ifjúság 2012. Tanulmánykötet. Budapest: Kutatópont, 38-53.

Nagy Á. - Tibori T. (2016): Narratívák hálójában: az ifjúság megismerési és értelmezési kísérletei a rendszerváltástól napjainkig. In Nagy Á. - Székely L. (szerk.): $N e$ gyedszázad. Magyar Ifjúság 2012. Budapest: Iuvenis Ifjúságszakmai Múhely - ISZT Alapítvány - Excenter Kutatóközpont - Új Ifjúsági Szemle Alapítvány, 400-432.

Nagy Á. - Trencsényi L. (2012): Szocializációs közegek a változó társadalomban - A nevelés esélyei: család, iskola, szabadidő, média. Budapest: Ifjúságszakmai Társaság Alapítvány.

Nyeste G. (2003): A magyar információs társadalom időmérlege. In Lengyel Gy. (szerk): Információs technológia és életminőség. Budapest: Corvinus Egyetem, 67-88.

Pintér R. - Székely L. (2006): Bezzeg a mai fiatalok - a tizenéves korosztály médiafogyasztása a többségi társadalom tükrében. In Dessewffy T. - Fábián Z. - Z. Karvalics L. (szerk.): Internet.hu - A magyar társadalom digitális gyorsfényképe 3. Budapest: Tárki Zrt., 137-160.

Somlai P. (2011): Nemzedéki konfliktusok és kötelékek. In Bauer B. - Szabó A. (szerk.): Arctalan (?) nemzedék. Ifjúság 2000-2010. Budapest: Nemzeti Család- és Szociálpolitikai Intézet, 25-36.

Szanyi-F. E. (2018): Nemzetközi diskurzusok az ifjúságkutatásban. In Székely L. (szerk.): Magyar fiatalok a Kárpát-medencében. Magyar Ifjúság Kutatás 2016. Budapest: Kutatópont Kft. - Enigma 2001 Kiadó és Médiaszolgáltató Kft., 11-40.

Székely L. (2006): Másvilág. Fiatalok az információs társadalomban. Új Ifjúsági Szemle, 4 (3): 35-45.

Székely L. (2007): A jövő médiafogyasztói. Új Ifjúsági Szemle, 5(1): 82-92.

Székely L. (2008): Fogyasztás, gazdasági helyzet, kultúra, média, infokommunikáció - Civil Ifjúsági Jelentés 2006-2007. Új Ifjúsági Szemle, 6(2-3): 67-74.

Székely L. (2014): Média multitasking. Az új generációk megváltozó médiafogyasztási és kommunikációs szokásairól. Doktori (PhD) értekezés. Budapest: Budapesti Corvinus Egyetem, Szociológia Doktori Iskola. DOI 10.14267/phd.2014015.

Székely L. (2018): A generációk megközelítése és önreflexiója. Médiapiac, 15(3-4): 12-4. Székely L. (2020): Szürke hattyúk. Budapest: Enigma 2001 Kiadó és Médiaszolgáltató Kft. Székely L. - Benczes R. (2019): Forever young senior. Generációs percepciók. In Ványi É. (szerk.): Múlt-jelen-jövő: a társadalomtudományi és nemzetközi kapcsolatok kar 30 éve. Budapest: Budapesti Corvinus Egyetem, 68-78. 